\title{
THE IMPLEMENTATION OF TEAM TEACHING LEARNING METHOD ON ISLAMIC EDUCATION SUBJECT IN KUPANG ELEMENTARY SCHOOL
}

\author{
Fajeri Arkiang ${ }^{1}$, Rabiatun Adwiah ${ }^{2}$ \\ ${ }^{1,2}$ Sekolah Tinggi Agama Islam, Kupang, Nusa Tenggara Timur, Indonesia \\ Email:fajriarkiang@stitkupamg.ac.id
}

\begin{abstract}
This study aimed to determine the implementation of team teachinglearning method on Islamic education subject in Kupang elementary school. This type of research was field research with a qualitative research method. The research took place at SDN 1 Bonipoi Kupang with the subjects of the study were the principal, 2 PAI teachers, and 49 fifth grade students. The data collection techniques used were interviews, observation, and documentation. The result showed that the team teaching method applied at SDN 1 Bonipoi Kupang was a full team teaching, where all learning activities were carried out jointly by the team teaching teacher, starting from the planning, implementation, and evaluation stages as well as the division of roles, tasks, and each responsibility. This team teaching method was very helpful for teachers and students in learning because 2 teachers collaborated with each other and worked together in learning process in class in such a way that led to the creation of effective and efficient learning.
\end{abstract}

Keywords: Education; Implementation; Teaching Team.

Abstrak: Penelitian ini bertujuan untuk mengetahui penerapan metode belajarmengajar tim pada mata pelajaran pendidikan Islam di sekolah dasar Kupang. Jenis penelitian ini adalah penelitian lapangan dengan metode penelitian kualitatif. Penelitian ini dilaksanakan di SDN 1 Bonipoi Kupang dengan subjek penelitian adalah kepala sekolah, 2 guru
PAI, dan 49 siswa kelas lima. Teknik pengumpulan data yang digunakan adalah wawancara, observasi, dan dokumentasi. Hasil penelitian menunjukkan bahwa metode pengajaran tim yang diterapkan di SDN 1 Bonipoi Kupang adalah pengajaran tim penuh, di mana semua kegiatan pembelajaran dilakukan bersama oleh guru mengajar tim, mulai dari tahap perencanaan, pelaksanaan, dan evaluasi serta pembagian peran, tugas, dan tanggung jawab masing-masing. Metode pengajaran tim ini sangat membantu guru dan siswa dalam belajar karena ada 2 guru yang saling berkolaborasi dan bekerja bersama dalam proses pembelajaran di kelas sedemikian rupa sehingga mengarah pada terciptanya pembelajaran yang efektif dan efisien.

Kata kunci: Implementasi; Tim Pengajar; Pendidikan.

\section{INTRODUCTION}

Quality education has become demands and needs that must be fulfilled by every educational institution, starting from the level of basic education to the level of higher education. In the process of education, teaching and learning activities are the most basic things done so that educational goals can be achieved, therefore teaching and learning activities are designed and run professionally. Faurrohman (2011) stated that "Teaching and learning activities contain a number of components which include objectives, 
learning materials, learning activities, teaching and learning activities, methods, tools, and resources as well as evaluation". These components are interrelated and have their respective roles in determining the success of the learning process in the classroom to create effective and efficient learning.

The same thing is also explained by Slameto (2010) that "In teaching and learning process, the teacher has the task to encourage, guide and provide learning facilities for students to achieve the goals, the teacher has the responsibility to see everything that happens in the classroom to help the process development in students". Meanwhile, according to Aqib (2003), "The task of the teacher is not just teaching, but more than that which leads students to become intelligent and virtuous adult humans. In this case, the teacher's role in forming attitudes, mental, and character is very dominant. Therefore, the teacher should pay attention to students, especially their attitudes, behavior, neatness, and discipline. Besides, the teacher should also pay attention to the habits and abnormalities, specificities, and strengths as well as weaknesses of each student".

Education in elementary school (SD) is an educational level that organizes education for six years (grades 1-grade 6). The teacher is tasked with providing basic abilities for students in terms of knowledge, attitudes, and skills, this aims as a provision for them to live in society and continue to a higher level of education. Islamic Education is one of the main subjects which is studied in elementary school. Thus, Marhamah (2002) stated that "Religious education is as general education, especially PAI, which aims to shape the behavior and personality of individuals in accordance with the principles and concepts of Islam in realizing moral values and religion as a basis for achieving general education goals". Therefore, Islamic education (PAI) has a very important position at the elementary level as at the age of the elementary school, children are the right age to instill the foundations of the teachings of Islam. Thus, in addition to being able to master the material, the teacher is also required to be able to master and use methods that vary according to the objectives to be achieved in teaching and learning activities. The teacher should be selective in choosing and applying learning methods in accordance with the material and characteristics of students. Delly (2017) in her article revealed that the success or failure of teachers in carrying out the teaching-learning process is largely determined by her or his ability to choose and use teaching methods.

In general, to date, the learning methods developed and applied in schools are carried out individually by the teacher starting from planning to evaluation, this results in the teacher having to work hard in creating conducive classes so that learning runs effectively and efficiently.

The realization of the demands and needs of quality education certainly cannot be separated from the learning process that occurs in schools, so researchers are interested in studying one of the concepts of learning undertaken by the teacher, the team teaching method. Implementing team teaching method in PAI learning is one way to help teachers better manage to learn. The team teaching-learning method is a form of learning method that involves 
two or more teachers who work together and collaborate in the learning process in the classroom. In line with the statement of Engkaswara (as cited in Karlina \& Fadli, 2020) that "Team teaching is a system of teaching conducted by two or more teachers, teaching a number of children who have differences in both interests, abilities and grade level". Meanwhile, according to Sudjana (2005) mentioned that "Team teaching is a method of teaching two or more teachers to work together to teach a group of students. Therefore, the class is faced by several teachers". Likewise, Ahmadi and Prasetya (as cited in Asmani, 2010) conveyed that Team teaching is "teaching carried out jointly by several teachers. The teaching team or teacher who presents the lesson material with the team teaching method presents the same lesson material in the same time and purpose. The teachers together prepare, implement, and evaluate student learning outcomes. The implementation of learning can be done in rotation with the lecturing method, or together with the panel discussion method.

According to Asmani (2010), the benefits of Team Teaching learning method are "improving the quality of teacher learning by working in teams. The implementation as a team is able to cover each other's weaknesses, as well as lighten the burden on individual teachers. One teaching team works together to plan and carry out learning at the same time. This situation is expected to create an atmosphere of learning which are effective, innovative, creative, challenging and fun".

The research to be carried out by this researcher is different from the research conducted by previous researchers. The research conducted by Damanik, Siahaan, and Tamba (2018) showed that the results of the data analysis that "the team teaching method applied in ABC Christian Sukoharjo was a semi full team teaching, where the teacher taught with the division of tasks, materials and hours on learning mathematics. The team teaching method with the distribution of material and teaching hours helped to overcome the teacher's situation and the need for mathematics learning in the school, but students had difficulty following the application of the team teaching method because they study two different topics in a week". Whilst the research that has been done by Darwin (2014), the results of his research showed that" (1) The implementation of teaching team for lecturers at the PTB FT Unimed Medan Study Program, in general, had not been carried out in accordance with the rules and concepts of "team teaching". (2) The absence of strict rules in the form of policies or guidelines for implementing "team teaching" both from the majors/ study programs and from the faculty. In fact, almost all learning courses are administered through "team teaching". Therefore, it is recommended that the team teaching pattern for PTB Unimed FT lecturers be imbued on the basis of team members' togetherness, both togetherness in planning, implementation, evaluation, and togetherness in conducting feedback on efficiency and efforts to improve the quality of the learning process in a planned and sustainable manner.

A research which was conducted also by Widodo (2013), his research showed that "the ineffectiveness of the use of team teaching for high schools in Yogyakarta was likely due to the team 
learning (team teaching) teachers tend to use one method or one learning model, so that teachers continued to use individual learning. They assumed that with team learning, the freedom of teachers to innovate in teaching and learning activities decreases. There were even some teachers who did not want to share their knowledge with fellow teachers who were members of a team". In contrast to the results of the research conducted by Ika (2018), the results of her research showed that "During the implementation of the cycle, the team teaching learning model could be said to be quite successful because it could increase student activity and learning outcomes. The same research was also conducted by Karlina and Rasam (2020), the results of their research showed "that, students whose learning activities used team teaching method could improve learning outcomes in mathematics economics courses".

And at this time, researchers will conduct a research related to the learning process with the implementation of the team teaching method at SDN 1 Bonipoi, which is one of the schools in Kupang where the learning process has implemented the team teaching method fully but only in class $\mathrm{V}$ in Islamic Education subject. This is done in connection with the large number of students in class V amounting 49 students, therefore the teachers have difficulties in controlling students when taught individually. The diversity of characteristics of the students require teachers to be more active in dealing with students who have different characteristics. At SDN 1 Bonipoi, in applying the team teaching method fully implies that in the learning process from preparation to evaluation carried out jointly by a team teaching teacher consisting of 2 teachers namely 1 core teacher and 1 assistant teacher who are responsible in accordance with each of their duties. Based on an explanation of the team teaching method that has been applied at SDN 1 Bonipoi, the researchers want to investigate further to be able to describe the implementation of team teaching in class $\mathrm{V}$ on Islamic education Subject at SDN 1 Bonipoi, Kupang.

\section{RESEARCH METHOD}

This research is a qualitative research with case study research method. Sampling in this study was conducted purposively. Winarni (2018) mentioned that purposive sampling is "sampling technique from data sources with certain considerations". The subjects in this study were the Principal, 2 PAI teachers, and 49 fifth grade students. The research was conducted at SDN 1 Bonipoi, Kupang. Data collection techniques were done by observation, interview and documentation study. The instrument in this study was the researcher himself. Mamik (2015) divided various forms of data based on the source, namely, "Primary data is the data obtained directly by the party whose data is needed. And secondary data is data that is not obtained directly from the party required data". The primary data in this study were obtained directly from the school principal, PAI teachers, and fifth grade students at SDN 1 Bonipoi. The secondary data obtained in this study were necessary documentation and field observations where the research was held. The data collected will be analyzed descriptively which consists of: 1) data reduction where the collected data will be selected and 
compiled, focusing on the implementation of team teaching learning, 2) displaying data, all collected and compiled data will be grouped to see the connectedness with each other, 3) drawing conclusions, after the data is collected, the researchers trace the interview transcripts, observations and documentation, so that they can be known which one should be displayed and which do not need to be displayed in order to obtain more in-depth conclusions.

\section{RESEARCH FINDINGS}

Planning for Team Learning Teaching Implementation at SDN 1 Bonipoi Kupang

Before conducting the learning process, the teachers first prepare a learning device in the form of lesson plans, syllabi and media that will be used when learning takes place. At this planning stage, the team teaching teachers compile lesson plan (RPP) together which is guided by the 2013 curriculum syllabus. This was conveyed by Mrs. Halimah (core teacher) at the interview saying that "Before the implementation of learning began, I with my colleague Mrs. Irma, compiled the lesson plans in advance and prepared other learning tools such as the media, so that when teaching in class the process went as planned". Developing and preparing a lesson plan (RPP) is very important to achieve the expected learning goals. This lesson plan is made so that in the learning process all learning activities undertaken by the teacher become more focused and the learning objectives can be achieved.

Regarding the learning model and the media which will be used during the learning, Mrs. Halimah said that "my partner and I used a method that was adapted to the material to be taught at the time, as well as the media we would use". In addition to preparing the lesson plan, preparing materials and media which will be used during learning, the more important is the teacher also divides the tasks, roles and responsibilities of each in accordance with the results of a joint agreement.

\section{The implementation of team teaching learning at SDN 1 Bonipoi Kupang}

At the implementation stage, each teacher have different duties and responsibilities. Where Mrs. Halimah (core teacher) and Mrs. Irma (assistant teacher). While the core teacher is assigned to deliver the material, the assistant teacher is tasked with supervising, assisting and assisting students who experience difficulties during learning. This was revealed by Mrs. Irma during the interview, "When Mrs. Halimah delivered the material, I was tasked with assisting, supervising students' behaviors and helping students who have difficulties so as not to interfere with other students thus learning runs effectively".

At the time of learning process, the team teaching teachers also exchanged roles in accordance with an agreement mutually agreed upon by the team teaching teachers.

As conveyed by Mrs. Irma (assistant teacher) in the interview that was conducted, "I and Mrs. Halimah sometimes exchanged the roles, for example at the first meeting, when I delivered the materials, Mrs. Halimah's task was to assist and help students, the second meeting, Mrs. Halimah delivered the materials and I accompanied the students, we did this division of work before teaching in class, so when 
compiling the learning materials we determined who would be in charge of delivering the material and duty to assist".

At the time of learning implementation, the team teaching teachers used various learning methods such as discussion as ell as question and answer, and used cooperative learning models. As the results of the interview delivered by Mrs. Halimah (core teacher), "in classroom learning, we used methods which were in accordance with the materials which we were going to convey, as well as the media that we used, thus the method we used could vary at each meeting depending on the materials that will be delivered". To measure the extent of students' understanding of the materials which have been taught, an evaluation was carried out. This evaluation can be done at the end of the lesson, and can be done in the middle of the semester as well as at the end of the semester.

In accordance with interviews conducted with Mrs. Halimah (core teacher) that "the evaluation we did was at each end of the lesson, so after the lesson was finished I did a question and answer session with students and gave assignments that they would do at home. While the formulation of questions for formative and summative evaluation we did it together but still divided the tasks in accordance with the sub themes that we conveyed during the implementation of learning".

Thus, the evaluation conducted by the team teaching teachers at Bonipoi elementary school was not only at each meeting but also at the end of each subtheme (daily/ weekly tests), formative evaluations (Mid Semester Exams) and summative evaluations (Final Semester Exams).

Obstacles and Fruitfulness in the Implementation of team teaching learning at SDN 1 Bonipoi Kupang

Based on the observations made in the implementation of the team teaching method, several obstacles were encountered, namely: 1) During the implementation of learning, the teacher assisted less attention and control of all students; 2) Some students still looked confused because there was often exchanging roles of the teachers in delivering the materials; 3) Lack of coordination between team teaching teachers in using learning methods and models in the classroom. In accordance with interviews conducted with Mrs. Halimah (core teacher) related to the determination of methods in learning implementation said that, "Sometimes we had different opinions in determining the methods used, especially we taught elementary school children who still wanted to play around, as a result, we had to really be able to selected and used the right method so that students were easy to absorb the lesson". At the same time, the interviews related to any obstacles faced by Mrs. Irma as the assistant teacher said "there were still some students who were busy playing alone sometimes disturbing other students, students who were slow in understanding also depend themselves on me".

Based from those obstacles, team teaching teachers coordinated with each other before learning started, discussing and reviewing again the related tasks, roles and each responsibilities after delivering the sub-themes in order to improve and 
minimize the existing obstacles for the next meeting.

Associated with how to motivate students in order not to get bored receiving the lessons, Mrs. Irma (assistant teacher) said that, "Usually I was more able to understand the characters of children, if they felt bored I immediately gave code to Mrs. Halimah to pause and afterwards asked the children to relax like clapping of prayer movements, clapping of wudhu, or others". This statement was also corroborated by Mrs. Halimah (core teacher) in the interview, she said that, "Before learning stopped, I usually gave encouragement or motivation so that students were always enthusiastic, and determined to become someone who is religious expert, therefore they become directed. By studying Islamic education, besides they have high knowledge, they also accompanied by good morals".

As stated by Mrs. Magdalena, as the principal of SDN 1 Bonipoi Kupang that, "the team teaching method was very helpful for students in daily learning in class. It also helped the teachers in teaching as the teachers could divided their respective tasks, the core teacher conveyed the materials and the assistant teacher accompanied and helped students, so that learning in the classroom could be better controlled. Regarding the obstacles faced by team teaching teachers, I was sure they were able to overcome this".

\section{DISCUSSION}

SDN 1 Bonipoi Kupang is one of the schools in Kupang that has implemented a team teaching learning method even though it does not apply the method in all classes and subjects. Team teaching learning method is one of the learning methods that involves two or more teachers who collaborate with each other in compiling learning tools and the process of learning activities in the classroom. Planning is very necessary before starting the learning process, this is related to the learning objectives to be achieved. The teachers must also be able to manage the class well in order to create effective and efficient learning.

As for the activities carried out by team teaching teachers of SDN 1 Bonipoi in planning are preparing everything well and carefully related to any activities that will be carried out during the learning process in the classroom, such as preparing materials, preparing lesson plans and syllabus, determining methods and learning models, determining media that can stimulate students' activities in accordance with the materials to be delivered, prepare evaluations that will be used after lessons take place and determining the tasks, roles and responsibilities of each teacher in managing the class.

This is corresponding with the theory put forward by Majid (2012) saying that in preparing learning plans there are several things that must be considered, namely: "1) understanding the curriculum, 2) mastering teaching materials, 3) preparing teaching programs, 4) implementing teaching programs, 5) assessing teaching programs and the results of teaching and learning processes that have been implemented". Meanwhile, according to Sudjana (2005) that "things that must be considered in planning the teaching team learning model one of which is the existence of a learning program that is arranged together by the team, so that it is clear and directed in 
accordance with the duties of each teacher in the team".

In learning implementation conducted by team teaching teachers of SDN 1 Bonipoi Kupang guided by the learning implementation plan that has been prepared, as for the obstacles encountered during the learning process, the assistant teacher (partner) can help overcome these obstacles. Therefore, in learning implementation, team teaching teachers of SDN 1 Bonipoi Kupang help each other in creating, managing and controlling classes appropriately so that teaching and learning activities are effective and efficient.

According to Soewalni (2007), there is a division of team teaching methods into two divisions namely, semi team teaching and full team teaching. If it is semi-team teaching, the process of learning formulation and evaluation are carried out together. The difference is in the process of implementing team teaching. It is because in the implementation of semi-team teaching, members who are members of the teaching team are not required to teach together. While in full team teaching, all team members, carry out planning, formulation, implementation and evaluation of learning outcomes together. Thus, it can be concluded that the team teaching conducted by SDN 1 Bonipoi Kupang is referred as in full team teaching, this can be clearly seen in the results of the research that has been presented, where all learning activities are carried out jointly by the team teaching teachers, starting from the planning stage, implementation, and evaluation as well as the division of roles, tasks and each responsibilities. In the implementation of team teaching at SDN 1 Bonipoi there are 2 teachers who teach in the classroom with their roles, duties and responsibilities, where the core teacher is assigned to deliver materials by methods/ models and media that have been determined jointly by the team teaching teachers, while the assistant teacher is assigned to assist, supervise, and control students during the learning process. At times this team teaching teachers can switch roles according to the agreement and the division of teaching time that they have set.

In evaluating, the teachers of team teaching at SDN 1 Bonipoi Kupang use formative evaluation and summative evaluation. According to Fathurrohman and Sutikno (2011), "Formative tests are presented in the middle of an education program to monitor the learning progress of students and educators. While the summative test is usually given at the end of the school year or at the end of an education level even though the meaning has been expanded to be used at the end of the quarterly or semester tests".

The evaluation activities carried out by the teachers of team teaching at SDN 1 Bonipoi Kupang include formative evaluations where each teacher gives feedback by doing questions and answers, giving assignments to do at home and besides the teachers also give tests at the end sub themes that have been studied. These are done to measure the ability of students to understand the lessons that have been delivered and also one way to measure the extent of the teacher's success in teaching.

In addition to evaluating the students, team teaching teachers evaluate each other by means of discussions and deliberations related to problems that arise during the learning process, what are the 
roles, tasks and responsibilities that have not been optimally carried out.

Similarly, it also explained by Ika (2018) that "If in a single teaching a teacher should master the class alone, then in team teaching from the beginning to the end of class learning is managed by all members of the teaching team. Thus, it allows the teaching process to be better because planning of learning is done together. The obstacles encountered during the implementation of learning can be discussed together to further find solutions to these problems. However, two or more heads will be better at making decisions because each team member complement each other's teammates' deficiencies. In team teaching, it requires a high level of cooperation among team members so that each member can carry out their respective tasks and the learning process can be carried out in accordance with the learning plan which has been created together".

This is in line with what is done by the team teaching teachers at SDN 1 Bonipoi, the team teaching teachers work together and collaborate from the beginning of planning to evaluation. Based on the observations of researchers, team teaching teachers are able to master and appreciate the subject matter delivered, can use a variety of methods and use of media thus, students are active in the learning process, team teaching teachers occasionally try diverse activities such as playing games, memorizing short surahs or other exciting things, giving awards in the form of praise and punishment to evoke the students' enthusiasm and motivation. As an assistant teacher (partner) he or she is able to assist, help and control students during the learning process so that students feel helped by the presence of 2 teachers in the classroom, learning runs effectively and efficiently. Thus, the obstacles that exist during the learning process take place can be overcome properly. This statement is relevant with the results of research conducted by Inti and Maryamah (2016) said that, "The team method, has shown its real effectiveness in the sense that can be relied upon as a good method to teach the field of study the history of Islamic culture at the madrasa ibtidaiyah level". There is not much different from the results of research conducted by Rahmawati (2018) that: "an increase in student motivation through team teaching is indicated by the average percentage in student learning motivation questionnaire, which is overall in the first cycle of $74.41 \%$ in the medium category to $87.28 \%$ in the high category of the second cycle".

\section{CONCLUSION}

From the results of this study, conclusions can be drawn as follows: 1) Planning team teaching at SDN 1 Bonipoi carried out collaboratively and together by 2 PAI teachers starting from preparing lesson plans (RPP) based on the existing syllabus, determining methods and models learning, determining the media and dividing roles, tasks and responsibilities when learning takes place later in the classroom. In this division of tasks, the core teacher is assigned to deliver the material while the assistant teacher is assigned to accompany, assist and control all student activities during the learning process. Therefore, it can be concluded that the type of team teaching at SDN 1 Bonipoi is full team teaching in which all learning activities are carried out jointly by the team teaching teachers; 2) In the 
implementation of team teaching at SDN 1 Bonipoi, the core teacher delivers the material in front of the class and the assistant teacher (partner) is assigned to accompany, assist and control the students so that learning runs effectively and efficiently. Whereas in terms of evaluating, the teaching of team teaching at SDN 1 Bonipoi is using formative and summative evaluations. Formative evaluation is where the teachers conduct questions and answers and gives test at the end of the lesson. While summative evaluation such as giving a repetition in each sub-theme that has been delivered, UTS and UAS. The evaluation questions are arranged jointly by the team teaching teachers; 3) Whereas for the obstacles faced by team teaching teachers and students can be overcome together by team teaching teachers by conducting deliberations and discussions and coordinating before learning begins. This team teaching method is very helpful for teachers in learning because there are 2 teachers who collaborate and work together in the learning process in class so that effective and efficient learning is created.

\section{REFERENCES}

Aqib, Z. (2003). Profesionalisme Guru Dalam Pembelajaran . Surabaya: Insan Cendekia.

Asmani, M. J. (2010). Pengenalan Dan Pelaksanaan Lengkap Microteaching \& Team Teaching. Yogjakarta: Diva Press.

Damanik, R. Y., Siahaan, M. F., \& Tamba, K. P. (2018). Penerapan Metode Team Teaching dalam Pembelajaran Matematika di SMA Kristen ABC Sukuharjo. JOHME :
Journal of Holistic Mathematics Education, 114-123.

Darwin. (2014). Pola Team Teaching Dosen Prodi Pendidikan Teknik Bangunan Fakultas Teknik Universitas Negeri Medan. Jurnal Manajemen Pendidikan Indonesia, 32-40.

Delly, D. (2017). Efektivitas Penggunaan Metode El-Syarif Dalam Meningkatkan Kemampuan Menghafal Mufrodat Siswa Di Madrasah Ibtidaiyah Al-Ishlah Palembang. Conciencia, 17(2), 1119.https://doi.org/https://doi.org/10 .19109/conciencia.v17i2.3481

Fathurrohman, P., \& Sutikno, S. (2011). Strategi Belajar Mengajar Melalui Penanaman Konsep Umum \& Konsep Islam. Bandung: PT Refika Aditama.

Ika, S. N. (2018, September). Implementasi Model Pembelajaran Team Teaching Untuk Meningkatkan Prestasi Belajar Siswa Bidang Studi Matematika Kelas VIII MTs Nurul Huda Genteng tahun ajaran 2017-2018 . Jurnal Darussalam : Jurnal Pendidikan, Komunikasi dan Pemikiran Hukum Islam, pp. 7898.

Inti, Y., \& Maryamah. (2016). Penerapan Metode Mengajar Beregu (Team Teaching) Dalam Meningkatkan Hasil Belajar Siswa Kelas IV pada Mata Pelajaran SKI di MI Muhammadiyah Ulak Lebar Kecamatan Ulu Ogan Kabupaten OKU. JIP : Jurnal Ilmiah PGMI.

Karlina, E., \& Fadli, R. (2020, April).

Penerapan Metode Pembelajaran Team Teaching Dalam Upaya 
Meningkatkan Hasil Belajar Mata

Kuliah Matematika Ekonomi Di

Unindra. Research and

Development Journal of

Education, pp. 65-73.

Majid, A. (2012). Perencanaan

Pembelajaran. Bandung:

RemajaRosdakarya.

Mamik. (2015). Metodelogi Kualitatif.

Sidoarjo: Zifatama Publisher.

Marhamah. (2002). Pengembangan Model

Pembelajaran Kelompok

(Cooperative Learning) Pada PAI

Sekolah Dasar. Bandung: Tesis pada SPS UPI.

Rahmawati. (2018). Meningkatkan

Motivasi Belajar Siswa Melalui

Pelaksanaan Team Teaching.

Jurnal Kabilah, 34-56.

Slameto. (2010). Belajar dan Faktorfaktor yang Mempengaruhinya. Jakarta: Rineka Cipta.

Soewalni, S. (2007). Team Teaching, Makalah Program Pelatihan Applied Approach 2007. Jakarta Selatan: Lembaga Pengembangan Pendidikan UNAS.

Sudjana, N. (2005). Dasar-dasar Proses Belajar Mengajar . Bandung: Sinar Baru Algensindo.

Widodo, S. A. (2013). Implementasi Team Teaching Terhadap Prestasi Belajar Siswa SMA kelas $\mathrm{X}$ se-Kota Yogyakarta pada Materi Trigonometri. UNION : Jurnal Pendidikan Matematika, 53-64.

Winarni, E. W. (2018). Teori dan Praktik Penelitian Kuantitatif Kualitatif, Penelitian Tindakan Kelas (PTK), Research and Development $(R \& D)$. Jakarta: Bumi Aksara. 